\title{
Livelihood Vulnerability and Migration Decision-Making Nexus: Case Studies from Rural Households in Nigeria
}

\author{
Osawe, Osayanmon Wellington \\ (Department Of Agriculture And Rural Development, School Of International Development, University Of East \\ Anglia, UK)
}

\begin{abstract}
This study examines the processes of migration decision-making and the livelihood vulnerability that rural farm households face in Nigeria. It focuses on the socio-economic and environmental factors such as how vulnerability at the household level interacts with the decision to migrate some members of the households to other destination using secondary data sources and the concept of household assets characteristics in explaining the link between livelihood vulnerability and migration decisions among rural households in Nigeria. The study argued that household assets mediate between the vulnerability that households experience and their decision to embark on migration as an alternative livelihood strategy and contrary to some findings, the study submitted that migration as a livelihood strategy of households is mainly used as an ex-ante risk management strategy-accumulation of assets rather than as an ex-post coping strategy to deal with stress or shocks confronting households.
\end{abstract}

Key Words: Livelihood; Vulnerability; Migration; Rural Households; Nigeria

\section{Introduction}

Over the past two to three decades, there have been a rising trend in migration (internal and international), vulnerability and livelihood insecurity in most rural areas in Sub-Saharan Africa (SSA) and Nigeria is not an exception. Various factors such as the global economic meltdown, negative effect of access to natural resources and environmental deterioration, climate changes, HIV/AIDS pandemic, population growth, negative effect of trade liberalization, adverse effects of globalization etc. (Ellis, 2006: 387; Baro and Deubel, 2006) have been adduced to this. It is imperative therefore to examine critically the interactions between livelihood vulnerability that household face and it possible effect on their migration decision. An understanding of the underlying complex interrelationship of persistent vulnerabilities of rural households and migration decision could help inform policy targeted at reducing poverty especially in the rural marginalised areas.

Addressing the issues of vulnerability has its advantages especially as it relates to poor rural households. For example, Alayande and Alayande (2004) opined that households face different kinds and magnitude of risk that may lead to a wide variation in their income from year to year including loss of productive asset. When there are not enough assets to reduce shocks or risk to livelihood therefore, household sometimes may experience losses including reduction in the quality and quantity of nutritious food intake, or sometimes school-aged children might temporarily or permanently stop schooling which can reduce household human capital base. These losses can increase household risk and vulnerability to poverty. Risk and vulnerability analysis among poor rural households according to some authors is important to an understanding of the social relations and decisionmaking processes that underlie households' livelihood diversification strategies such as migration patterns (Blaikie et al., 1994; Ellis, 2000).

It is also increasingly recognised that the Nigerian economy is mainly made up of a rural agrarian sector with an increasing level of diversification either within or outside the agricultural sector (Canagarajah and Thomas, 2001; Omonona, 2009). In Nigeria especially in the rural marginalised areas that are mainly agrarian, livelihood decisions and strategies are informed by several factors. For example, they are embedded in the political and institutional ecology of migration and diversification strategies, climate change, environmental and natural disasters to even rural-urban market and/or trade imbalances, income inequality, entitlement failures and so on (Sen, 1981; Eakin and Luers, 2006).

Just like most African economies, Nigeria's rural agricultural sector is characterised by small-scale resource-poor farmers and also by informal traders cutting across both gender groups (Omonona, 2009). Nigeria is endowed with significant resources including human resources, land, oil and other natural resources. However, a significant proportion of the population are still vulnerable and others experience extreme poverty (Omonona, 2009). Poverty and vulnerability in Nigeria according to Canagarajah and Thomas (2001), is strongly influenced by the educational system and the level of education of the citizenry, age and the nature of employment system in Nigeria. Those without an education constitute a large fraction of the poor and the extreme poor (Canagarajah and Thomas, 2001). These groups of people are often marginalized and face 
significant challenges in building a sustainable and secure livelihood. The poor land rights and land tenure security system especially in poor communities often exacerbate this livelihood challenges. Most of this population group often decides to migrate to places which they feel are better suited to make a living and send remittances back home. But more often than not, this is not always the case. For example, a review of current literature shows that sometimes those who move often end up being worse-off than what they were before while others often mingle their way through to survive (see de Haan et al., 2000).

Although, there is an increasing amount of literature on migration decision-making, poverty and vulnerability in SSA including Nigeria, however, the limitation of some of these studies are that most are focused on description and estimation of migrants and migration trends and development (see Brockerhoff, 1994; Okali et al., 2001; de Haan, 2006) while other studies on vulnerability have focused significantly on the environmental ecology of vulnerability (see Eakin and Luers, 2006; Adelekan, 2009). This study is therefore intended to fill the gap of identifying the complex relationship between the processes of vulnerability and migration decision-making among marginalised poor rural households in Nigeria. Specifically, the research seeks to answer the following questions:

1. What are the factors that determine household vulnerability to poverty in Nigeria?

2. Why are some rural households more vulnerable than others in Nigeria?

3. What role does migration play in household vulnerability analysis in Nigeria?

\section{Conceptualizing Vulnerability To Poverty And Migration Decision-Making}

Vulnerability has been defined in several different ways. For example, Chaudhuri et al. (2002:1) defined vulnerability, as the "ex-ante risk today that a household will, if currently poor, remain poor, or if currently non-poor will fall below the poverty line next period". There is now a shift in focus from measuring poverty as a fixed non-dynamic concept to an understanding of issues of vulnerability among rural households (see Moser, 1998; World Bank, 2001; Quisumbing, 2002; Alayande, 2002; Alayande and Alayande, 2004).

Notwithstanding all the different definitions put forward to underpin a conceptualization of vulnerability, it is clear that the term vulnerability deals generally with the problems of household's poverty, risks and uncertainty (Blaikie et al., 1994; Ellis, 2000; Oni and Yusuf, 2007). Other authors have tended to distinguish between the concept of household livelihood vulnerability and poverty in both academic discourse and in the field of development. It is argued that vulnerability is in part, different from poverty since the concept of poverty is an 'ex-post' measure of a household's well-being, while vulnerability is an 'ex-ante' analysis of a household's well-being (Chaudhuri, 2003). However, there is an existence of a conceptual linkage between poverty and vulnerability. Accordingly, Bidani and Richter (2001) opined that changes in vulnerability are also most of the time consistent with poverty trends. For example, when the vulnerability of different part of the population group is to be assessed at the present and in the future, household's vulnerability may be seen as the likelihood that the household will experience poverty in the near future (Chaudhuri, 2003).

\subsection{Risk, Risk-Management And Coping Strategies In Vulnerability Analysis}

The role of risk in poverty and vulnerability analysis and the strategies households deploy to address the exposure to various sources of risks have been discussed in the literature (Hoogeveen et al., 2004). Two types of risks have been identified. First is the 'common or aggregate risk' defined as aggregate, economy-wide risks that affect all members of a community or region and second, is the 'idiosyncratic or individual risk' defined as risks that affect individuals within a community or geographical region (Hoogeveen et al., 2004). However, in practice, risks may not be wholly common or idiosyncratic because it could be a mix of both common and idiosyncratic due to several reasons (Deaton, 1997). For example, Dercon (2002) revealed from a panel data study on Ethiopia that most of the shocks experienced by the sampled households included both idiosyncratic and common risk attributes.

It may be helpful therefore to have a clear understanding of the nature of the different sources of risks that households face, since it is increasingly acknowledged that households respond to risks in different ways (Dercon, 2002). The degree and kind of response is further heightened by the uncertainty of future occurrences within the household. The uncertainty regarding the future that household face according to Chaudhuri (2003:3) originate from the diverse sources of risk including issues such as, "harvests may fail, food prices may rise, the main income earner of the household may become ill" etc.

This could be justified for the reason why Moser argued for the primacy of individuals' or households' asset as a determinant of vulnerability: 
"Analysing vulnerability involves identifying not only the threat but also the 'resilience' or responsiveness in exploiting opportunities, and in resisting or recovering from the negative effects of a changing environment. The means of resistance are the assets and entitlements that individuals, households, or communities can mobilise and manage in the face of hardship. Vulnerability is therefore closely linked to asset ownership. The more assets people have the less vulnerable they are, and the greater the erosion of people's assets, the greater their insecurity" (Moser, 1998:3).

\subsection{Migration: A Livelihood Strategy}

Prowse (2003:19) noted that one aspect of vulnerability which has so far been neglected in policy and academic discourse is that of the "response to risk, uncertainty and shocks". The distinction between ex-ante risk management strategies and ex-post coping strategies had been discussed in the earlier part of this chapter. Analysis at this level could justify some of the reasons why there is a considerable debate on migration decision-making as a livelihood risk-response strategy of the poor either from the individual perspective or at the household level. Migration has also been differentiated as a gendered process in the literature. For example, Gubhaju and De Jong (2009) noted that while microeconomic theory usually assumes that males are the household migration decision makers and females are mainly constrained in terms of making the decision to migrate (Pedraza, 1991; Riley and Gardner, 1993; Pessar, 1999), new household economic theory takes into consideration the gender and power dynamics that is at play within the household.

In summary, available literature seems to come to a convergence that while there are several reasons why people decides to migrate from personal characteristics, life cycle changes to structural push and pull factors, the decision to actually move is not solely an individual phenomenon but an interplay of household relations among members. For example, before a person moves, social networks including friends, family relations, kinship ties from home and destination areas, the potential prospect from destination areas, the extent of income inequality between home and destination areas, enough resources to finance the movement, the amount and extent of risk factor prevailing at home, gender implication etc are all taken into consideration. These considerations are in themselves not solely specific to individual persons but would affect generality of the household or community.

\subsection{Livelihood Vulnerability and Migration Decision Schema}

Household vulnerability analysis structured around the analysis of the relationship between household level decision-making and opportunity cost (cost of forgone alternative) mediated through available assets could provide a powerful tool for an understanding of the diversity of household vulnerability. It may also help in identifying intervention points to effectively address the issues of household vulnerability as they emerge locally (WorldFish Centre, 2010). In the vulnerability literature, several activities towards reducing household's vulnerability have been classified as either ex-ante risk management strategy or as ex-post coping strategy (Sinha and Lipton, 1999; Dercon, 2002). Ex-ante risk management strategies are prospective strategies employed to enhance household capacity to respond to a risk situation before it occurs such as diversifying the sources of household income e.g. combining agriculture and other paid wage work outside of agriculture or agriculture and migration strategies etc while ex-post coping strategies are employed to reduce, mitigate or deal with an adverse risk situation that household is currently experiencing (see Ellis, 2000; Hulme et al., 2001; Chaudhuri, 2003). However, the challenge in rural development policy is in deciding on the appropriate and best intervention point either as ex-ante risk management intervention or as ex-post coping strategy intervention that will effectively improve household's well-being (Prowse, 2003). In figure 1, I depict a schematic framework to illustrate the relationship between threat to household livelihood, migration decision and household riskresponse strategies in relation to livelihood vulnerability that could help us to understand this concept better. 


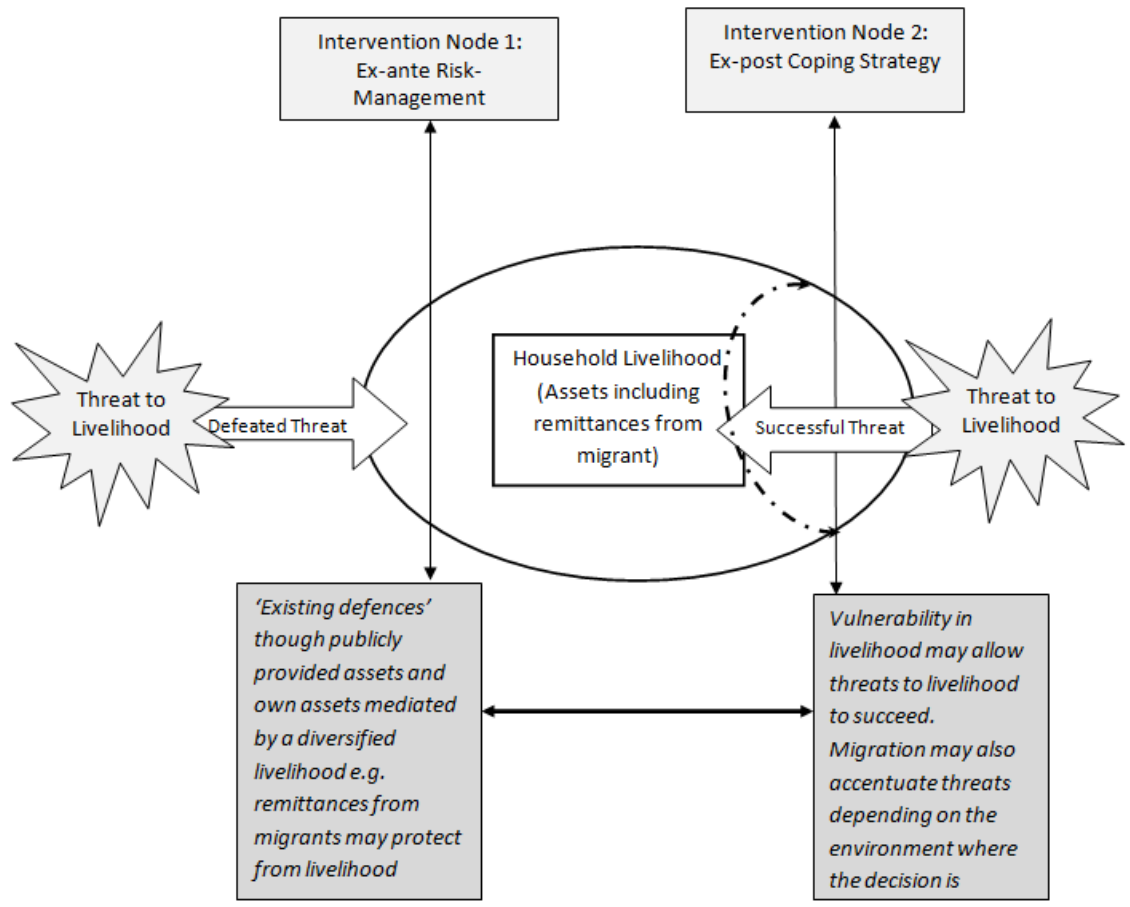

Figure 1: Livelihood Vulnerability and Migration Decision Schema

\section{Methodological Approach}

This research uses the concept of household assets characteristics to explain the link between livelihood vulnerability and migration decisions. Amount of assets that household has such as level of education of household head, gender and age of household head, occupation of head and other members of the household, income sources, land and other productive asset ownership etc is used for the analysis in describing how assets ownership mediate between household risks, vulnerability and migration decisions (see Moser, 1998; Whitehead, 2002). This analysis has been deemed necessary, since previous studies have submitted that migration decision as a household livelihood strategy could have varying degree of consequences that may be beneficial or detrimental depending on household level characteristics, institutional, and environmental factors (de Haan, 1999; de Haas, 2010; de Haas and Fokkema, 2010). All data used in this analysis are from secondary sources.

\subsection{Contextual Analysis}

The analysis of the lives and livelihoods of households and the strategies they deploy in the face of risks and shocks to their livelihood security can help to bring into focus some of the processes that make people vulnerable to poverty. And the amount of the capacity that the household has will determine the degree of the effect of any stress that it undergoes (Moser, 1998). Thus, it may be safe to say that poverty may occur when there is an interaction between an already vulnerable household and an adverse situation. The extent of damage that the adverse situation will have on the household will be dependent on both the severity of the adverse situation and the household level characteristics in terms of the assets (human, social, financial, natural and physical) that is available to mobilise at the time (Moser, 1998; Bebbington, 1999). For example, it is argued that, most households whose members migrate usually are vulnerable to poverty and deprived of assets such as education, age and gender of household head, occupation of household head, savings, sometimes land ownership, etc (Chaudhuri et al., 2002; Oni and Yusuf, 2007) and in a bid to cushion the effect of livelihood shock and enhance their capacity to cope, they may then send some members of the household to urban cities in order to receive remittances from them (de Haas, 2006). And, acknowledging that rural households in reality has different segments in terms of demography, occupational composition and other socio-economic characteristics, and the characteristics of the community that the household resides (de Haan, 1999; Oni and Yusuf, 2007; Omonona 2009; de Haas, 2010), the level of vulnerability that they face may be quite different and the response they employ to deal with such vulnerabilities could also be different. Therefore, it is necessary to understand how the household characteristics mediate between the responses to and the level of vulnerability experienced by household. In the next section, I present some data to understand this contextual relationship specifically reviewing the relationship between some household level characteristics, migration decision-making and 
vulnerability among rural households in Nigeria and to verify the argument that migration is a result of high vulnerability or poverty among rural households.

\subsubsection{Age of Household Heads}

From Table 1, looking at the age categorization of vulnerability to poverty, the data seems to suggest that households headed by persons aged 21-40 (whether male or female) are less vulnerable to poverty in comparison to other households whose heads are either below the age of 21 or above 40 years. Similarly, Table 5 reveals that households within the age group of 15 and 44 are more likely to be migrant compare to other age group above this range. A likely reason to this may be that those household whose heads are between the age range of 21 to 40 are in the prime of their life and they have the strength to provide more labour hours to work in own farmland, engage in other non-farm wage-earning activities or provide labour needs at destination areas for those who migrate and in this way, diversify their income sources to move out of poverty. For example, Bryceson (2002) noted that older people were increasingly being concentrated in farming activities rather than diversification than the younger generation in the different regions that were studied including Nigeria and also Mustapha (1999) associated farming in cocoa with older heads of households in Nigeria. Similarly, Omonona (2009:14) argued that "most rural households are involved in farming either as secondary or primary occupation and the ability to do hard and difficult work, of which farming is one, decreases with increase in age". This in effect can act to reduce household income and therefore increase vulnerability. In this perspective, age could be seen either as an asset or a threat to rural household livelihood security. It is an asset for those who are young and can diversify their income sources outside of agriculture and threat for some older people who may not be able to engage in other wage-earning work apart from farming.

\subsubsection{Education Level of Household Heads}

The observed poverty level from Table 1 reveals that the incidence of poverty is highest in households without education and vulnerability to poverty decreases for households with primary, secondary and tertiary educations respectively. The vulnerability level of household heads with at least a tertiary education level is quite small (0.07353) as seen in Table 1. This tend to suggest that household heads that are more educated may have better opportunity to get higher wage jobs that will help to improve their household well-being. More so, though there are marginal differences, households with lower levels of education are more likely to migrate as shown in Tables 3 and 4. An explanation to this could be that households with higher levels of education may be able to diversify their income sources and also attract higher wage paying jobs either at home or away. Though, the likelihood of this happening depends on the job market opportunities that are available. For example, in a report of a gender and growth assessment in Nigeria, Rao et al. (2009) noted certain disparities in the relationship between level of education and wage. While the remuneration status of women especially was related to their educational status, skills etc in Bauchi State for instance, but in some other places like Cross River State; returns to education were low due largely to lack of employment opportunities. Also, they noted that "because of lack of employment opportunities after education, many parents withdraw their children from school in favour of income generation, vocational training or begging" (p.32). Iversen and Palmer-Jones (2008) also suggested that there is an association between the education levels of household members that affect household overall welfare. For example, on the relations of husband who went to school with other members of the household that did not go and how this affects the household well-being. If we take this into account, education level of not just the household head only but also of other members of the household will be helpful in enhancing household capacity to cope with or manage any exposure to risks and shocks depending on external conditions such as job market opportunities that are easily accessible.

\subsubsection{Gender of Household Heads}

Gender of household head is also seen as an important determinant of household vulnerability. In Tables 1 and 2, the data shown indicate that both male- and female-headed households are vulnerable to poverty with the male-headed households marginally more vulnerable to poverty than their female counterpart. However, in terms of actual or observed poverty status, figures in Table 1 shows that female-headed households are poorer than male-headed households with poverty indices of 0.53068 and 0.52370 respectively. Also, Rao et al. (2009b) reported a trend in lower poverty levels in households headed by female in majority of the zones that were studied in Nigeria. More so, in terms of the relationship between gender and migration decision-making, the data in Tables 3 and 4 seems to be consistent with the fact that households whose head is a male, is more likely to migrate. In which case, there is a higher probability that when confronted with a potentially adverse situation such as income loss, the husband as household head will most often migrate before any other member of the household. For example, Iliya (1999:23) reported in a study in Northern Nigeria that "migrants were all males and women on their own do not migrate except when they marry and move to their husband's home area". Having said this, irrespective of gender, it could be worth noting to state that the type and severity of risk 
or shocks confronting the households (either ex-ante or ex-post) and the availability of the necessary capital to finance the movement will influence the decision to migrate.

\subsubsection{Occupation of Household Heads}

Looking at poverty indices in terms of occupation indicates higher levels of poverty among farming households than non-farming households as shown in Table 1. Similarly, Table 2 revealed that household head in the agricultural sectors (and predominantly a rural income-generating activity) have a higher share of the poor and those who are vulnerable compared to household heads in other occupation types. The vulnerability to poverty of households in this sector is understood since agriculture is a seasonal occupation and is most vulnerable to weather and climatic changes. The kind of occupation that household engage in can be crucial in determining vulnerability because seasonal occupation like farming or other low wage paying jobs can be a threat to livelihood when the household is exposed to a potentially devastating adverse situation such as weather fluctuation resulting to drought or famine, crop failure, debt etc. For example, Whitehead (2002) in an analysis of a study in North eastern Ghana, noted some implications of the occupation strategies deployed by household members on livelihood security e.g. in the type of crops farmed, household relations in managing available labour supply, remittances from outside, gendered allocation of work etc. She noted that for those household heads that were able to either diversify or intensify their income sources through various farm and off-farm activities including migrating some members to the south to receive remittances and with a reasonable household composition (with more adults), had lower vulnerability and poverty status than the other households that were involved in the survey. Similarly in Nigeria, Iliya (1999) reported an increase in vulnerability among households engaged in farming which were mainly due to weather fluctuations inherent in farm-related activities; therefore more households were increasingly diversifying their income sources out of agriculture in order to sustain a living. He noted further that "for many households, returns from farming are inadequate to see them through the year" (p.26). The type of occupation households engage in is therefore, very crucial in level and outcome of household vulnerability.

\subsubsection{Household Size}

The size of the household sometimes may potentially have a positive effect on the livelihood sustainability of the household. For example, in most rural communities, large family size (comprising those who are able to provide enough labour hours) may indicate more labour availability to cultivate more farm lands, engage in domestic household chores and sometimes to engage in other wage work outside of the farm such as migration to provide remittances back home (Meagher, 1999; Dillon et al., 201). For example, Whitehead (2002) in a study in North eastern Ghana noted that household well-being was more closely related to the size of the household (especially the number of adult male or female) and noting that while smaller households were poorer, the households that had more members were richer. However, figures in Table 1, show that households with large family size have a higher share of vulnerability and are more prone to be poor in future. Also, while Table 3 suggests that migrant households tend to be smaller, Table 4 seems to suggest otherwise that households with higher household composition have more migrant than those with lower household sizes. For example, Meagher (1999) noted a higher average number of migrants among the households with higher composition in a study in Northern Nigeria. These evidences however, are important to us in explaining the differing migration and vulnerability experiences of households with differing household characteristics. In the event therefore of vulnerability and an adverse threat to household livelihood, migration decision will not be influenced by household composition alone but also on factors such as how vulnerable is the household to risk, availability of enough capital to finance migrant, norms, measure of perceived returns, severity of hazards or threat to livelihood etc (Prowse, 2003; Mberu, 2005; de Haas and Fokkema, 2010).

\subsubsection{Regional Characteristics}

From figures in Table 2, the share of the households in rural areas in poverty is 90.2 percent, whereas the share of the households in the urban areas is only 9.8 percent. The poverty level of the rural households is much higher than that of the urban centres at 57.8 percent and 66.8 percent for urban and rural areas respectively. This may have further confirmed the review of relevant literature on this issue that poverty is much pronounced in rural Nigeria compared to urban areas. More so, figures from Table 1 seems to suggest that rural households in the north eastern geopolitical zone of Nigeria have higher levels of vulnerability (0.67777) while the least vulnerable are rural households in the south south region $(0.36526)$. In real terms, these values are still very high. In this regard, Omonona (2009:16) argued that this high poverty gap may have been "connected with 
the differences in the agro-climatic conditions in the northern and southern part of Nigeria in which the south produces the primary export crops, including cocoa, palm kernel and palm oil as well as maize while the main agricultural produce of the north are mainly staples such as sorghum, millet, cowpea, groundnut, and livestock, and also rice and wheat in limited wetland areas". More so, in terms of regional characteristics, the religious inclination of the region is a factor in determining the level of diversity that households can incorporate into their livelihood to move out of poverty. For example, RaD (2011) and Omonona (2009) noted that religion play different roles in the economic development of rural households taking evidences from predominantly Muslim North (Sharia Law) and Christian South in Nigeria. Also, Mberu (2005:154) argued on the implication of religion and ethnicity on the propensity to migrate among rural households, noting that "the Urhobo-Edo-Isoko is 9.4 times and the Igbo-Ibibio 4.4 times as likely as the Hausa-Fulani to be rural-urban migrants". Thus, whichever regional categorization that we may look at, it is clear that vulnerability and poverty levels are quite high in rural households in Nigeria and this varies for different regions. For example, taking account of the rural-urban inequality, Iliya (1999:9) in a study in Northern Nigeria argued that in Nigeria, the "growing incidence of construction work and the quest for higher education have, among other factors, attracted streams of migrants". This according to the study was due mainly to the relatively high vulnerability experienced in most households in rural areas in Nigeria compared to their urban counterparts. This presupposes that poverty increases the propensity to migrate i.e. poorer households in rural areas tend to have more migrant. However, in the next chapter, I present some evidences to the contrary that migration is more a livelihood accumulation strategy among rural households in Nigeria.

\section{Analysis of Migration And Vulnerability Findings}

It could be interesting to note that in an analysis of household socio-economic relations, it is possible that some households may find themselves in a good or bad condition because past choices had unintended consequences (Glewwe and Hall, 1998). One of such choice among rural households may be the decision to migrate a member of the household to another destination in order to provide remittances to either reduce household risks or shocks or cope with existing threats to livelihood.

\subsection{Assets}

The assets composition of any household is very crucial to it survival (Moser, 1998; Bebbington, 1999). This is even truer for any poverty and vulnerability analysis among rural households just as Chambers (2006) noted that household's net asset is a major indicator of household vulnerability. Assets in this regard also include remittances that rural households receive from their migrants as seen in Figure 1. Tables 1 to 4, reveals that households with fewer asset values including household composition, level of education, capital base, occupation etc were more vulnerable compared to others with larger asset values. Also, in terms of asset, the characteristics of each person or group within the household were also vital in determining vulnerability and the decision to migrate e.g. age, gender of household members etc as seen in Tables 3 and 4. More so, a composition of household asset value that could help in defeating any threat to household livelihood either as ex-ante risk management or as an ex-post coping strategy is the presence of 'external defences' (figure 1) such as publicly provided services e.g. health care facilities, good water supply, accessible roads and other social safety net services specifically targeted at the most vulnerable and poor households (Oni and Yusuf, 2007; Omonona, 2009). Also, figures in Tables 1 and 2 show clearly that households with higher share of the vulnerable and the poor are those with fewer asset composition and in most of these regions in Nigeria where surveys were conducted, authors noted that government presence in terms of provision of basic social amenities (external defences) were very minimal. This allude to the fact that, household defences through both own assets and public provided mediated by a diversified livelihood is necessary to reducing vulnerability and taking households out of poverty.

\subsection{RISKS}

Several formal and informal strategies are available and used by households to reduce vulnerability and to manage any adverse situations that they are confronted with. One of such strategies as seen in Tables 3 and 4 is the process of migration. However, the kind of strategy household deploy will depend on the type and severity of adverse situation that they face. This will therefore determine if the strategy employed will be as an ex-ante risk management or as an ex-post coping strategy as seen in Figure 1. Data in Tables 3 and 4 show clearly that the decision to migrate a member of the household to other areas is skewed more to the ex-ante risk management strategy rather than as an ex-post coping strategy. The reason being that our expectation is that households with lower asset value will probably send some members to other destination such as the process of fostering that was hinted by Ehindero et al. (2006) where poor families send members (mostly children) to urban cities in Nigeria. However, in Table 4, migrant households are seen to have lower land size but a higher mean livestock and household capital values. Implying that these households on the average were better-off compared 
to the other non-migrant households. This is because, for households with lower asset value and are experiencing higher levels of vulnerability, financing a member of the household to other locations can be quite difficult. The implication is that, these households will prefer to use the available labour at home to cope with the risk they face rather than sending them away. This indicates that migration is preferably used as an ex-ante household risk management strategy rather than as an ex-post coping strategy.

\subsection{LEVELS OF MIGRATION DECISION-MAKING}

From the foregoing discussions, it is clear that the decision to migrate to other destinations is dependent on several factors that are not just individualistic in nature but also include a combination of household relations with particular focus on the reason for migration either as a way to manage risk (ex-ante) or as a way of coping (ex-post strategy). For example, taking the prevailing vulnerability situation at home into consideration, a person will move when issues such as how much other members of the household can contribute to financing the movement, effect on household of a short of labour hours that would have been provided by the person who is moving, the prevailing economic and political situation at destination areas etc have been sorted out. In Tables 1 to 4 , the level of vulnerability experienced by each sample household and the decision to migrate are particularly connected to variables such as household size, gender, ethnic origin, religious inclination etc that are all not unrelated to household level characteristics. Furthermore, careful note is taken of the fact that migration decision-making (not just in Nigeria alone) is determined by the interaction of vulnerability situation, not just with individual attributes alone but also with household and community/regional characteristics (De Jong, 2000). In this respect, $\operatorname{RaD}(2011: 2)$ noted that "the wellbeing that most people seek is essentially social, not purely individual: it is focused on the family and community".

From above, we see that ceteris paribus (all things being equal), vulnerability is closely linked with both assets characteristics of rural households and on the ingenuity of households in mobilizing these assets in the best possible strategy. The strategies employed such as decision to migrate members of the family to other destinations also have varying effect. For example, the evidences pointed out to the fact that the effect of migration on vulnerability varies for different rural household groups depending on characteristics such as household asset composition, the degree and level of household vulnerability experienced, regional characteristics etc. And consequentially, the analysis revealed that migration is preferably used as an ex-ante risk management strategy-asset accumulation, rather than as ex-post coping strategy-to deal with stress or shocks.

\section{Conclusion}

The study examined the relationship between the vulnerability that rural household's face and the decision to migrate using secondary data sources to examine these processes from rural households in Nigeria. It is clear from several findings that there exist a relationship between the type and severity of vulnerability that rural households are faced with and how this affects the decision to send one or more members of the household to other destination in order to receive remittances back home. The dissertation has also shown that more often than not, migration decisions are not just embedded on individual decision-making but a complex interaction of individual attributes household and community characteristics. More so, households that have fewer assets base are more likely to be poor and have higher levels of vulnerability and households within a particular geographical location will tend to experience varying levels of vulnerability depending on several reasons such as the amount of assets that they have including the kind of occupation they are engaged in, the type and severity of risks that they are confronted with, the specific characteristics of each person's within the given households, the degree of presence of publicly provided support either from the government or other donor agencies etc (Moser, 1998; Bebbington, 1999). More so, Bebbington (1999:2022) noted that "people's assets are not merely means through which they make a living: they also give meaning to the person's world".

Furthermore, migration as a livelihood strategy by households according findings is mainly used as an ex-ante risk management strategy rather than as an ex-post coping strategy. The importance of this is seen as Chambers (2006:6) opined that "it seems more cost-effective besides more humane, to use such means to reduce vulnerability and prevent improvement than, once people are poorer or destitute to try to enable them to recover". This line of thought suggests to the fact that migration as an ex-ante risk management is vital to reducing risk and vulnerability that confront households.

Conclusively, this study in examining the relationship between livelihood vulnerability and migration decision-making in rural households in Nigeria has provided further insights to the large body of literature on vulnerability and determinant of migration decision-making in rural areas. However, a further area of research in examining this linkage could be focused on vulnerability and migration intentions among urban households and also on behavioural studies that could track vulnerability levels among migrant and their sending households with time. 


\section{References}

[1]. Adelekan, I.O. (2009) Vulnerability of Poor Urban Coastal Communities to Climate Change in Lagos, Nigeria. Fifth Urban Research Symposium 2009.

[2]. Adepoju, A. (1983) Selected Studies on Dynamics, Patterns and Consequences of Migration: Medium-Sized Towns in Nigeria, Vol. 4. Paris: UNESCO.

[3]. Adepoju, A. (1986) Rural Migration in Nigeria. Ile-Ife: Department of Demography and Social Statistics, University of Ife.

[4]. Adger, W.N. (1998) Indicators of Social and Economic Vulnerability to Climate Change in Vietnam. CSERGE Working Paper, GEC 98-02. Centre for Social and Economic Research on the Global Environment, University of East Anglia and University College London.

[5]. Alayande B.A. (2002) Determinants of Vulnerability to Poverty. A World Bank Commissioned Study.

[6]. Alayande, B.A. and Alayande, O. (2004) A Quantitative and Qualitative Assessment of Vulnerability to Poverty in Nigeria. A Paper submitted for presentation of CSAE Conference on Poverty reduction, Growth and Human Development in Africa, March, 2004. Assessed on $16^{\text {th }}$ May, 2012.

[7]. Alwang, J., Siegel, P.B., and Jorgensen, S.L. (2001) Vulnerability: A View from Different Disciplines. Social Protection Discussion Paper Series. Social Protection Unit, The World Bank. Washington.

[8]. Apata, T.G., Apata, O.M., Igbalajobi, O.A. and S. M. O. Awoniyi, S.M.O (2010) Determinants of Rural Poverty in Nigeria: Evidence from Smallholder Farmers in South-western, Nigeria. Journal of Science and Technology Education Research, Vol. 1 (4), pp. $85-91$.

[9]. Astone, N. and McLanahan, S. (1994) Family Structure, Residential Mobility and School Report: A Research Note. Demography. Vol. 31, pp: 575-584.

[10]. Bah, M., CissE, S., Diyamett, B., Diallo, G., Lerise, F., Okali, D., Okpara, E., Olawoye, J. and Tacoli, C. (2003) Changing RuralUrban Linkages in Mali, Nigeria and Tanzania. Environment and Urbanization, Vol. 15 (1), pp: 13-24

[11]. Baker, J. and Aina, T.A. (1995) The Migration Experience in Africa. Uppsala: Nordiska Africa institutet.

[12]. Bebbington, A. (1999) Capitals and Capabilities: A Framework for Analysing Peasant Viability, Rural Livelihood and Poverty. World Development, Vol. 27 (12), pp: 2021-2044,

[13]. Bidani, B. and Richter K. (2001) Household Vulnerability and the Asian Crisis: The Case of Thailand. Washington DC: The World Bank.

[14]. Bird, K., Hulme D., Moore K. and Shepherd, S. (2002). Chronic Poverty and Remote Rural Areas. CPRC Working Paper No. 13. International Development Department, School of Public Policy, University of Birmingham.

[15]. Blaikie, P.M., Cannon, T., Davis, I., and Wisner B., (1994) At Risk: Natural Hazards,People's Vulnerability and Disasters. London [16]. and New York: Routledge Publisher.

[17]. Bohle, H.G. (2001): Vulnerability and Criticality. In: Newsletter of the International Human Dimensions Programme on Global Environmental Change, Update No. 02/2001

[18]. Bryceson, D.F. (2002) The Scramble in Africa: Reorienting Rural Livelihoods. World Development, Vol. 30 (5) pp: $725-739$.

[19]. Buijs, G. (1993). Migrant Women: Crossing Boundaries and Changing Identities. Oxford: Berg. pp. 1-20

[20]. Canagarajah, S. and Thomas, S. (2001) Poverty in a Wealthy Economy: The Case of Nigeria. Journal of African Economies, Vol. 10 (2), pp: 143-173

[21]. Cannon, T., Twigg, J., and Rowell, J. (2003) Social Vulnerability, Sustainable Livelihoods and Disasters. Report to DFID Conflict and Humanitarian Assistance Department (CHAD) and Sustainable Livelihoods Office, London.

[22]. Cardona, O.D. (2004) The Need for Rethinking the Concepts of Vulnerability and Risk from a Holistic Perspective: A Necessary Review and Criticism for Effective Risk Management. In: Bankoff, G.; Frerks, G.; D. Hilhorst (Ed.): Mapping Vulnerability: Disasters, Development and People. London. pp. 37-51.

[23]. Case, A. and Deaton, A. (1998) Large Cash Transfers to the Elderly in South Africa. Economic Journal, Vol. 108 (450), pp: 13301362 .

[24]. Chambers, R. (2006) Vulnerability, Coping and Policy (Editorial Introduction. Institute of Development Studies Bulletin, Vol. 37, Number 4

[25]. Chambers, R. (1983) Rural Development: Putting the Last First. Longman: Essex, UK

[26]. Chambers, R. (1989) Vulnerability: How the Poor Cope. Institute of Development Studies Bulletin, Vol. 20, Number 2

[27]. Chant, S. and Radcliffe, S.A. (1992) Migration and Development: The Importance of Gender, Chapter 1, in S. Chant (ed.), Gender and Migration in Developing Countries, London: Belhaven Press.

[28]. Chaudhuri, S. (2001) Empirical Methods for Assessing Household Vulnerability to Poverty. Mimeo, School of International and Public Affairs, Columbia University.

[29]. Chaudhuri, S. (2003) Assessing Vulnerability to Poverty: Concepts, Empirical Methods, and Illustrative Examples, Columbia University, Mimeo.

[30]. Chaudhuri, S., Jalan, J., and Suryahdi, A. (2002) Assessing Household Vulnerability to Poverty from Cross-sectional Data: A Methodology and Estimates from Indonesia. Department of Economics, Columbia University, New York, NY 10027. Discussion Paper No: 0102-52

[31]. Chi, G. and Voss, P. (2005) Migration Decision-making: A Hierarchical Regression Approach. Journal of Regional Analysis and Policy. Vol. 35 (2), pp: 11-22.

[32]. Christiaensen, J.L. and Subbarao, K. (2004) Towards an Understanding of Household Vulnerability in Rural Kenya. World Bank

[33]. Policy Research Working Paper, 3326.

[34]. Clark, D. and Murphy, C. (1996) County-wide Employment and Population Growth: An Analysis of the 1980s. Journal of Regional Science. Vol. 36, pp: 235-256.

[35]. DaVanzo, J. (1981) Micro-economic Approaches to Studying Migration Decisions. in Migration Decision Making: Multidisciplinary Approaches to Micro-level Studies in Developed and Developing Countries, edited by R.W. Gardner. New York: Pergamon Press.

[36]. Dayton, J. and Ainsworth, M. (2002) The Elderly and AIDS. Coping Strategies and Health Consequences in Rural Tanzania. Population Council: Policy Research Division Working Paper Number 160.

[37]. Deaton, A. (1997) The Analysis of Household Survey: A Microeconomic Approach. Baltimore, Md.: Johns Hopkins University Press

[38]. Dercon, S. (2002) Income Risk, Coping Strategies and Safety Nets. The World Bank Research Observer, Vol. 17 (2), pp: $141-166$. The World Bank

[39]. de Haan, A. (1999) Livelihoods and Poverty: The Role of Migration. Journal of Development Studies, Vol. 36 (2), pp: 1-47. 


\section{Livelihood Vulnerability And Migration Decision-Making Nexus: Case Studies From Rural}

[40]. de Haas, H. (2006) International Migration and National Development: Viewpoints and Policy Initiatives in Countries of OriginThe case of Nigeria. Working Papers: Migration and Development series Report 6 prepared for Radboud University, Nijmegen and Directorate General for International Cooperation (DGIS), Ministry of Foreign Affairs, the Netherlands.

[41]. de Haas, H. (2010) Migration and Development: A Theoretical Perspective. International Migration Review, Vol. 44, pp: $227-264$.

[42]. de Haas, H. and Fokkema, T. (2010) Intra-Household Conflicts in Migration Decision-Making: Return and Pendulum Migration in Morocco. Population and Development Review 36(3), pp: 541-561.

[43]. De Jong, G. F. (2000) Expectations, Gender, and Norms in Migration Decision-Making. Journal of Population Studies. Vol. 54, pp: 307-319

[44]. Dercon, S. (2005) Vulnerability: A Marco Perspective. A paper Presented at the 2005 Annual Bank conference on Development Economics. The World Bank, Amsterdam

[45]. Devereux, S. (2001) Livelihood Insecurity and Social Protection: A Re-emerging Issue in Rural Development. Development Policy Review, Vol. 19 (4), pp: 507-519

[46]. Dillon, A., Mueller, V. and Salau, S. (2011) Migration Responses to Agricultural Risk in Northern Nigeria. American Journal of Agricultural Economics, Vol. 93 (4), pp: 1048-1061

[47]. Dreze, J. and Sen, A.K. (1989) Hunger and Public Action. Clarendon : Oxford, UK

[48]. Elbers, C., Lanjouw, J.O. and Lanjouw, P. (2002) Micro-level Estimation of Welfare. Policy Research Working Paper, No 2911. The World Bank.

[49]. Ehindero, S., Awolowo, O. and Idemudia, P. (2006) Baseline Study on Forced Labour and Human Trafficking in Kwara, Kano, Cross Rivers and Lagos State in Nigeria. Abuja: ILO/PATWA Offices in Nigeria, Ghana, Sierra Leone and Liberia.

[50]. Ellis, F. (1998) Household Strategies and Rural Livelihood Diversification. Journal of Development Studies, Vol. 35 (1), pp: 1-38

[51]. Ellis, F. (2000) Rural Livelihoods and Diversity in Developing Countries. Oxford University Press : Oxford, UK

[52]. FOS (1999) Poverty and Agricultural sector in Nigeria: Poverty Incidence of Farmers by Region. Federal Office of Statistics: Abuja, Nigeria.

[53]. Fischer, I. and Buchenrieder, G. (2010) Risk Management of Vulnerable Rural Households in Southeast Asia. Adaptive Management in Subsistence Agriculture, WS 2.5, pp: 1279-1288. 9th European IFSA Symposium, 4-7 July 2010, Vienna (Austria)

[54]. Fuguitt, G. V. and Brown, D. L. (1990) Residential Preferences and Population Redistribution. Demography. Vol. 27, pp: 589-600.

[55]. Gaiha, R. and Imai, K. (2008) Measuring Vulnerability and Poverty: Estimates for Rural India. UNU-WIDER Research Paper No $2008 / 40$

[56]. Gelderblom, D. (2005) Toward a Synthetic Model of Migration, in P. Kok, D. Gelderblom, J. O. Oucho and J. van Zyl (eds) Migration in South and Southern Africa. Cape Town: HSRC Press, pp. 268-290.

[57]. Glewwe, P. and Hall, G. (1998) Are Some Groups Most Vulnerable to Macroeconomic Shocks than Others? Hypothesis Test Based on Panel data from Peru. Journal of Development Economics, (56) pp. 181-126

[58]. GTZ (2005) Linking Poverty Reduction and Disaster Risk Management. German Technical Cooperation. Eschborn.

[59]. Gubhaju, B. and De Jong, G.F. (2009) Individual versus Household Migration Decision Rules: Gender and Marital Status Differences in Intentions to Migrate in South Africa. International Migration Vol. 47 (1), pp: 31-61.

[60]. Harris, J. R. and Todaro, M. P. (1970) Migration, Unemployment and Development: A Two-Sector Analysis. American Economic Review, Vol. 60, pp: 126-142.

[61]. Hoddinot, J. and Quisumbing, A. (2003) Methods for Micro-econometric Risk and Vulnerability Assessments. Social protection Discussion Paper Series No. 0324. The World Bank.

[62]. Hoogeveen, J.G. (2005) Measuring Welfare for Small but Vulnerable Groups: Poverty and Disability in Uganda. Journal of African Economies, Vol. 14 (4), pp. 603-631

[63]. Hoogeveen J.G., Tesliuc, E., Vakis, R. and Dercon, S. (2004) 'A Guide to the Analysis of Risk, Vulnerability and Vulnerable Groups. Washington.

[64]. Hulme, D., Moore, K., and Shepherd, A. (2001) Chronic poverty: meanings and Analytical Frameworks. CPRC Working Paper No 2, Institute for Development Policy and Management, University of Manchester.

[65]. Iliya, M. A. (1999) Income Diversification in the Semi-arid Zone of Nigeria: A Study of Gigane, Sokoto, North-west Nigeria. ASC Working Paper, Vol. 39. Kano: Centre for Research and Documentation (CRD) and Leiden: African Studies Centre.

[66]. Iversen, V. and Palmer-Jones, R. (2007) Literacy Sharing, Assortative Mating, or What? Labour Market Advantages and Proximate Illiteracy Revisited. Journal Of Development Studies 44 (6), pp: 797-838.

[67]. Jacoby, H. and Skoufias, E. (1997) Risk, Financial Markets, and Human Capital in a Developing Country. Review of Economic Studies, Vol. 64 (3), pp: 311-335.

[68]. Kamanou, G. and Murduch, J. (2002) Measuring Vulnerability to Poverty. NYU Wagner Working Paper, No. WP1012. New York: New York University.

[69]. Kazianga, H. and Udry, C. (2006) Consumption Smoothing? Livestock, Insurance, and Drought in Rural Burkina Faso. Journal of Development Economics, Vol. 792, pp: 413-446.

[70]. Kirkby, J., O'Keefe, P. and Howarth, C. (2001) Introduction: Rethinking Environment and Development in Africa and Asia. Journal of Land Degradation and Development, Vol. 12, pp: 195-203

[71]. Kochar, A. (1995). Explaining Household Vulnerability to Idiosyncratic Income Shocks. American Economic Review, Vol. 85 (2), pp:159-164.

[72]. Kochar, A. (1999). Smoothing Consumption by Smoothing Income: Hours-of-Work Responses to Idiosyncratic Agricultural Shocks in Rural India. Review of Economics and Statistics, Vol. 81 (1), pp: 50-61.

[73]. Makoka, D and Kaplan, M. (2005) Poverty and Vulnerability - An Interdisciplinary Approach. Centre for Development Research, University of Bonn. MPRA Paper No. 6964, February 2008

[74]. Meagher, K. (1999) If the Drumming Changes, the Dance also Changes: De-agrarianization and Rural Non-farm Employment in Nigerian Savannah. ASC Working Paper, Vol. 40. Kano: Centre for Research and Documentation (CRD) and Leiden: African Studies Centre.

[75]. Mberu, B. U. (2005) Who Moves and Who Stays? Rural Out-Migration in Nigeria. Journal of Population Research. Vol. 22 (2), PP: $141-161$

[76]. Mincer, J. (1978) Family Migration Decisions. Journal of Political Economy. Vol. 86 (5), pp: 749-773.

[77]. Moser, C. and Mcllwaine, C. (1997) Household Responses to Poverty and Vulnerability, Volume 2. The World Bank: Washington, DC.

[78]. Moser, C. (1998) The Asset Vulnerability Framework: Reassessing the Urban Poverty Reduction Strategies. World Development, Vol.26 (1) pp.1-19 


\section{Livelihood Vulnerability And Migration Decision-Making Nexus: Case Studies From Rural}

[79]. Mustapha, A. R. (1999). Cocoa farming and income diversification in South-western Nigeria. ASC Working Paper, Vol. 42. Kano: Centre for Research and Documentation (CRD) and Leiden: African Studies Centre.

[80]. Oluwatayo, I. B. (2004) Income Risk and Welfare Status of Rural Households in Nigeria. Ekiti State as a Test Case Research Paper No. 2004/61. World Institute for Development Economic Research (WIDER).

[81]. Omonona, B.T. (2009) Knowledge Review of Poverty and Rural Development in Nigeria. Nigeria Strategic Support Program (NSSP). Report No. NSSP 003

[82]. Oni, O.A and Yusuf, S.A. (2007) Determinants of Expected Poverty Among Rural Households in Nigeria. African Economic Research Consortium (AERC)

[83]. Olurode, L. (1995) Women in Rural-Urban Migration in the Town of Iwo in Nigeria. pp. $289-302$ in J. Baker and T.A. Aina (eds), The Migration Experience in Africa. Uppsala, Sweden: Nordiska Africainstitutet.

[84]. Pedraza, S. (1991) Women and Migration: The Social Consequences of Gender. Annual Review of Sociology, Vol. 17, pp: 303325.

[85]. Pessar, P. R. (1999) The Role of Gender, Households, and Social Networks in the Migration Process, in C. Hirschman et al. (eds), Handbook of International Migration, New York: Russell Sage Foundation, pp. 53-70.

[86]. Posel, D. (2003) Have Migration Patterns in Post-apartheid South Africa Changed? Paper Prepared for the Conference on African Migration in Comparative Perspective. Johannesburg, South Africa.

[87]. Prowse, M. (2003) Towards a Clearer Understanding of 'Vulnerability' in Relation to Chronic Poverty. Chronic Poverty Research Centre, CPRC Working Paper No 24, April, 2003.

[88]. Quisumbing A. R. (2002) Consumption Smoothing, Vulnerability and Poverty in Rural Bangladesh. International Food Policy Research Institute, Washington DC 2006. Preliminary Draft.

[89]. Quisumbing, A. R. (2009) Intergenerational Transfers and the Intergenerational Transmission of Poverty in Bangladesh: Preliminary Results from a Longitudinal Study of Rural Households, Chronic Poverty Research Centre Working Paper No. 117.

[90]. RaD (2011) Religion and Development in India, Pakistan, Nigeria and Tanzania: Inspirational or Inhibiting? Religion and Development (RaD) Policy Brief No 21

[91]. Rao, N., Palmer-Jones, R., Papyrakis, E., Akanji, B., Akpokodje, G., Ajala, B. (2009) Gender and Growth Assessment in Nigeria. Bauchi, Cross River, Kano and Lagos State Reports. Funded by the Department for International Development (DFID) and Canadian International Development Agency (CIDA)

[92]. Rao, N., Palmer-Jones, R., Papyrakis, E., Akanji, B., Akpokodje, G., Ajala, B. (2009b) Gender and Growth AssessmentMicroeconomic Study. Funded by the Department for International Development (DFID) and Canadian International Development Agency (CIDA)

[93]. Riley, N. E. and Gardner, R.W. (1993) Migration Decisions: The Role of Gender, in United Nations. Internal Migration of Women in Developing Countries, New York: ST/ESASER.R/127, pp: 195-206.

[94]. Rosenzweig, M. and Stark, O. (1989) Consumption Smoothing, Migration, and Marriage: Evidence from Rural India. Journal of Political Economy, Vol. 974, pp: 905-926.

[95]. Sell, R. R. and DeJong, G. F. (1978) Towards a Motivational Theory of Migration Decision Making. Journal of Population. Vol. 1 (4), pp: 313-335

[96]. Sen, A. (1981) Poverty and famines: An Essay on Entitlement and Deprivation. Clarendon Press: Oxford

[97]. Sinha, S. and Lipton, M. (1999) Damaging Fluctuations, Risk and Poverty: A Review. Background Paper for the World Development Report 2000/2001, Poverty Research Unit, University of Sussex, Brighton, UK.

[98]. Skoufias, E. (2002) Measuring Household Vulnerability to Risk. Some Estimates from Russia. International Food Policy Research Institutes, Washington DC.

[99]. Smith, S.K., Tayman, J. and Swanson, D.A. (2000) State and Local Population Projections: Methodology and Analysis. New York: Kluwer Academic/Plenum Publishers.

[100]. Stark, O. (1991) The Migration of Labour. Cambridge and Oxford: Blackwell

[101]. Subbarao, K. and Coury, D. (2004) Reaching Out to Africa's Orphans: A Framework for Public Action. Washington DC: World Bank.

[102]. Taylor, J. E. (1999) The New Economics of Labour Migration and the Role of Remittances in the Migration Process. International Migration, Vol. 37, pp: 63-88.

[103]. Thywissen, K. (2006) Glossary of Core Terms of Disaster Risk Management. In: Birkmann, J. (Ed.): Measuring Vulnerability to Hazards of Natural Origin. Tokyo.

[104]. Todaro, M. P. (1969) A Model of Labour Migration and Urban Unemployment in Less-Developed Countries. American Economic Review, Vol. 59, pp: 138-148

[105]. Tunali, I. (2000) Rationality of Migration. International Economic Review. Vol. 41 (4), pp: 893-920.

[106]. Watts, M. J. and Bohle, H. G. (1993) The Space of Vulnerability: The Causal Structure of Hunger and Famine. Progress in Human Geography, Vol. 17(1), pp: 43-67.

[107]. Whitehead, A. (2002) Tracking Livelihood Change: Theoretical, Methodological and Empirical Perspectives from North-East Ghana. Journal of Southern African Studies, Vol. 28 (3), pp: 575-598. Special Issue: Changing Livelihoods.

[108]. Wisner,B. (1993) Disaster Vulnerability: Scale, Power and Daily Life. GeoJournal, Vol. 30 (2), pp: 127-140

[109]. World Bank (1996) Nigeria Poverty in the Midst of Plenty: The Challenge of Growth with Inclusion. A World Bank Poverty Assessment. Report No. 14733-UNI. Population and Human Resources Division, Western Africa Department, Africa Region, The World Bank: Washington, D.C.

[110]. World Bank (2001): The World Development Report. The World Bank: Washington, D.C.

[111]. Zachariah, K.C. and Conde, J. (1981) Migration in West Africa: Demographic Aspects. A Joint World Bank OECD Study. Oxford: Oxford University Press.

[112]. Zimmerman, F. and Carter, M. (2003) Asset Smoothing, Consumption Smoothing, and the Reproduction of Inequality Under Risk and Subsistence Constraints. Journal of Development Economics, Vol. 71, pp: 233-260 


\section{APPENDIX}

Table 1: Expected Poverty (Vulnerability) of Rural Households in Nigeria using Demographic or Socioeconomic Characteristics

\begin{tabular}{|c|c|c|c|c|}
\hline $\begin{array}{l}\text { Demographic/ } \\
\text { Socio-economic } \\
\text { Characteristics } \\
\end{array}$ & $\begin{array}{l}\text { Expected poverty } \\
\text { (Vulnerability) }\end{array}$ & Observed poverty & $\begin{array}{c}\text { Predicted Poverty } \\
\text { Ratio } \\
\end{array}$ & \\
\hline \multicolumn{5}{|l|}{ Geopolitical Zone: } \\
\hline North Central & & 0.56335 & 0.47729 & 1.180 \\
\hline North East & & 0.67777 & 0.53289 & 1.272 \\
\hline North West & & 0.55394 & 0.54826 & 1.010 \\
\hline South East & & 0.45599 & 0.55159 & 0.827 \\
\hline South South & & 0.36526 & 0.50224 & 0.727 \\
\hline South West & & 0.61444 & 0.52589 & 1.168 \\
\hline \multicolumn{5}{|l|}{ Educational Level: } \\
\hline No formal Education & & 0.67623 & 0.56533 & 1.196 \\
\hline Primary Education & & 0.28219 & 0.43938 & 0.642 \\
\hline Secondary Education & & 0.21785 & 0.43116 & 0.505 \\
\hline Tertiary Education & & 0.07353 & 0.48039 & 0.153 \\
\hline \multicolumn{5}{|c|}{ Farming or Non farming: } \\
\hline Farming & & 0.54611 & 0.53925 & 1.013 \\
\hline Non Farming & & 0.48910 & 0.46221 & 1.058 \\
\hline \multicolumn{5}{|l|}{ Gender: } \\
\hline Male & & 0.53587 & 0.52370 & 1.023 \\
\hline Female & & 0.53077 & 0.53068 & 1.0002 \\
\hline \multicolumn{5}{|c|}{ Age of Household Head: } \\
\hline 21 or Less & & 0.55172 & 0.52542 & 1.050 \\
\hline 21 to 40 & & 0.50081 & 0.52301 & 0.958 \\
\hline 41 to 60 & & 0.56237 & 0.52300 & 1.075 \\
\hline 61 and above & & 0.55473 & 0.48357 & 1.147 \\
\hline \multicolumn{5}{|l|}{ Household Size } \\
\hline 1 person household & & 0.45185 & 0.47637 & 0.949 \\
\hline 2 to 6 & & 0.52200 & 0.53045 & 0.984 \\
\hline 7 to 10 & & 0.60562 & 0.53345 & 1.135 \\
\hline Above 10 & & 0.78818 & 0.51220 & 1.539 \\
\hline
\end{tabular}

Source: Oni and Yusuf (2007)

Table 2: Poverty and Vulnerability Profiles within Different Segments of the Population

\begin{tabular}{|c|c|c|c|c|c|c|c|}
\hline & $\begin{array}{c}\text { Population } \\
\text { share }\end{array}$ & $\begin{array}{c}\text { Share of } \\
\text { poor }\end{array}$ & $\begin{array}{c}\text { Share of } \\
\text { vulnerable }\end{array}$ & $\begin{array}{c}\text { Poverty } \\
\text { head-count }\end{array}$ & $\begin{array}{c}\text { Mean } \\
\text { vulnerabilit } \\
\mathrm{y}\end{array}$ & $\begin{array}{l}\text { Vulnerability } \\
\text { head-count }\end{array}$ & $\begin{array}{c}\text { Vulnerabilit } \\
\mathrm{y} \text { to poverty } \\
\text { rate }\end{array}$ \\
\hline Total & 100 & 100 & 100 & 63.5 & 68.5 & 87.0 & 1.37 \\
\hline $\begin{array}{l}\text { Sector of Residence: } \\
\text { Urban } \\
\text { Rural }\end{array}$ & $\begin{array}{l}21.35 \\
78.65\end{array}$ & $\begin{array}{c}9.8 \\
90.2\end{array}$ & $\begin{array}{c}9.0 \\
91.0\end{array}$ & $\begin{array}{l}57.8 \\
66.8\end{array}$ & $\begin{array}{l}65.7 \\
70.2\end{array}$ & $\begin{array}{l}70.9 \\
89.0\end{array}$ & $\begin{array}{l}1.23 \\
1.33\end{array}$ \\
\hline $\begin{array}{l}\text { Sex of Household Head: } \\
\text { Male } \\
\text { Female }\end{array}$ & $\begin{array}{l}86.42 \\
13.58\end{array}$ & $\begin{array}{c}91.2 \\
8.8\end{array}$ & $\begin{array}{c}99.0 \\
1.0\end{array}$ & $\begin{array}{l}63.8 \\
60.8\end{array}$ & $\begin{array}{c}71.2 \\
61.2^{\prime}\end{array}$ & $\begin{array}{l}77.4 \\
61.2\end{array}$ & $\begin{array}{l}1.21 \\
1.54\end{array}$ \\
\hline $\begin{array}{l}\text { Education level of Househo } \\
\text { Head: } \\
\text { No Education } \\
\text { Primary } \\
\text { Secondary } \\
\text { Tertiary }\end{array}$ & $\begin{array}{c}61.13 \\
21.09 \\
12.85 \\
4.93 \\
\end{array}$ & $\begin{array}{c}66.90 \\
17.33 \\
11.47 \\
4.30 \\
\end{array}$ & $\begin{array}{c}92.7 \\
3.4 \\
2.6 \\
1.1 \\
\end{array}$ & $\begin{array}{l}69.2 \\
55.2 \\
55.3 \\
49.0 \\
\end{array}$ & $\begin{array}{l}74.7 \\
59.7 \\
58.6 \\
59.9 \\
\end{array}$ & $\begin{array}{l}78.6 \\
69.3 \\
71.6 \\
33.6 \\
\end{array}$ & $\begin{array}{l}1.14 \\
1.26 \\
1.29 \\
0.69 \\
\end{array}$ \\
\hline \multicolumn{8}{|c|}{ Occupation of Household Head: } \\
\hline Professional/Technical & 3.42 & 3.5 & 0.4 & 56.4 & 66.4 & 84.4 & 1.50 \\
\hline Administration & 0.15 & 0.2 & 4.8 & 43.7 & 83.7 & 87.9 & 2.01 \\
\hline Clerical and related & 4.56 & 5.1 & 2.4 & 58.2 & 63.4 & 81.9 & 1.41 \\
\hline Sales' Workers & 14.59 & 15.7 & 3.8 & 57.6 & 63.2 & 56.4 & 0.98 \\
\hline Service industry & 1.23 & 1.2 & 0.3 & 64.1 & 54.1 & 67.9 & 1.06 \\
\hline Agriculture and Forestry & 67.12 & 66.1 & 86.7 & 68.0 & 70.8 & 78.9 & 1.16 \\
\hline Production and transport & 1.35 & 1.8 & 0.4 & 64.9 & 79.2 & 83.5 & 1.29 \\
\hline Manufacture and processing & 1.63 & 1.6 & 0.5 & 51.7 & 68.3 & 80.3 & 1.55 \\
\hline Students and apprentice & 3.01 & 2.7 & 0.3 & 47.5 & 66.0 & 34.2 & 0.72 \\
\hline Others & 2.93 & 2.1 & 0.6 & 50.3 & 64.4 & 64.7 & 1.29 \\
\hline
\end{tabular}

Source: Alayande and Alayande (2004) 
Livelihood Vulnerability And Migration Decision-Making Nexus: Case Studies From Rural

Table 3: Distribution of Migration Status According to Socio-economic Characteristics

\begin{tabular}{|c|c|c|c|}
\hline Variables & Rural Non-migrant & Rural-rural Migrant & Rural-urban Migrants \\
\hline \multicolumn{4}{|l|}{ SEX } \\
\hline Male & 50.1 & 51.1 & 53.4 \\
\hline Female & 49.9 & 48.9 & 46.6 \\
\hline \multicolumn{4}{|l|}{ ETHNIC ORIGIN } \\
\hline Hausa-Fulani & 35.4 & 35.1 & 15.3 \\
\hline Yoruba & 15.2 & 16.1 & 8.3 \\
\hline Igbo-Ibibio & 21.4 & 21.9 & 40.1 \\
\hline Kanuri-Shua Arab & 5.8 & 3.8 & 0.5 \\
\hline Tiv-Igala-Idoma & 9.2 & 7.8 & 20.4 \\
\hline Urhobo-Isoko-Edo & 4.1 & 1.6 & 9.1 \\
\hline Nupe-Kamberi-Gwari & 2.0 & 4.9 & 2.9 \\
\hline Others & 6.8 & 8.9 & 3.2 \\
\hline \multicolumn{4}{|l|}{ RELIGION } \\
\hline Christian & 39.9 & 44.0 & 70.2 \\
\hline Muslim & 56.1 & 54.0 & 29.5 \\
\hline Other & 4.0 & 2.0 & 0.3 \\
\hline \multicolumn{4}{|l|}{ AGE } \\
\hline $15-29$ & 46.9 & 43.3 & 39.4 \\
\hline $30-44$ & 27.5 & 33.3 & 39.9 \\
\hline $45-59$ & 14.6 & 15.0 & 16.0 \\
\hline $60+$ & 10.9 & 8.4 & 4.6 \\
\hline \multicolumn{4}{|l|}{ EDUCATION } \\
\hline$<$ Primary & 59.6 & 59.2 & 24.8 \\
\hline Full Primary & 27.3 & 24.1 & 29.9 \\
\hline Full Secondary & 10.3 & 11.8 & 29.2 \\
\hline Higher Education & 2.7 & 4.9 & 16.1 \\
\hline \multicolumn{4}{|l|}{ HOUSEHOLD SIZE } \\
\hline $1-5$ & 42.6 & 51.8 & 52.1 \\
\hline $6-10$ & 40.4 & 37.2 & 42.2 \\
\hline $11+$ & 16.9 & 10.9 & 5.7 \\
\hline \multicolumn{4}{|l|}{ RELATION TO HEAD } \\
\hline Head & 31.4 & 37.7 & 46.6 \\
\hline Spouse & 30.5 & 35.9 & 31.7 \\
\hline Son/Daughter & 30.4 & 18.6 & 8.3 \\
\hline Non/other Relative & 7.6 & 7.8 & 13.4 \\
\hline TOTAL & $\mathrm{n}=18,656$ & $\mathrm{n}=16,311$ & $\mathrm{n}=9,594$ \\
\hline
\end{tabular}

Source: Mberu, 2005

Table 4: Descriptive Statistics of Households by Migration Status

\begin{tabular}{lc|c|c|c}
\hline \multicolumn{1}{c}{ Socio-economic Characteristics } & \multicolumn{2}{c}{$\begin{array}{c}\text { Non-migrant Households } \\
\text { Mean }\end{array}$} & $\begin{array}{c}\text { Migrant } \\
\text { Households } \\
\text { Mean }\end{array}$ & $\begin{array}{c}\text { Difference in Means } \\
\text { t-Statistics }\end{array}$ \\
\hline Household Size & 6.90 & 9.53 & $-9.12^{* * *}$ \\
Share of boys in household & 0.48 & 0.39 & $2.84^{* * *}$ \\
Share of girls in household & 0.33 & 0.40 & $-2.90^{*}$ \\
Male as household head & 0.93 & 0.90 & 0.70 \\
Head has primary education & 0.24 & 0.44 & $-2.98^{*}$ \\
Head has secondary education & 0.15 & 0.15 & 0.07 & -0.27 \\
Livestock value & 1546.04 & 1813.07 & -1.00 & 0.35 \\
Household capital value & 815.17 & 1248.27 & & \\
Land size & 4.94 & 4.66 & 144 & \\
Number of households & 41 & & \\
\hline
\end{tabular}

Source: Dillon et al. (2011)

${ }^{* * *} p<0.01,{ }^{* *} p<0.05,{ }^{*} p<0.10$. 